\title{
Emigration of a colony of the leaf-cutting ant Acromyrmex heyeri Forel (Hymenoptera, Formicidae)
}

\author{
Mariane Aparecida Nickele ${ }^{1}$, Marcio Roberto $\mathrm{Pie}^{2} \&$ Wilson Reis Filho ${ }^{3}$
}

\begin{abstract}
${ }^{1}$ Programa de Pós-graduação em Entomologia, Laboratório de Dinâmica Evolutiva e Sistemas Complexos, Departamento de Zoologia, Universidade Federal do Paraná, Caixa Postal 19020, 81531-980, Curitiba-PR, Brasil. nickele.mariane@gmail.com

${ }^{2}$ Laboratório de Dinâmica Evolutiva e Sistemas Complexos, Departamento de Zoologia, Universidade Federal do Paraná, Caixa Postal 19020, 81531-980, Curitiba-PR, Brasil. pie@ufpr.br

${ }^{3}$ Epagri/Embrapa Florestas, Estrada da Ribeira, Km 111, Caixa Postal 319, 83411-000 Colombo-PR, Brasil. wilson@cnpf.embrapa.br
\end{abstract}

\begin{abstract}
Emigration of a colony of the leaf-cutting ant Acromyrmex heyeri Forel (Hymenoptera, Formicidae). Colony migration is a poorly studied phenomenon in leaf-cutting ants. Here we report on the emigration of a colony of the leaf-cutting ant $A$. heyeri in Brazil. The colony emigrated to a new location $47.4 \mathrm{~m}$ away from the original nest site, possibly because it had undergone considerable stress due to competitive interactions with a colony of Acromyrmex crassispinus.
\end{abstract}

KEYWORDS. Attini; interspecific aggression; leaf-cutting ant; nest relocation.

RESUMO. Emigração de uma colônia da formiga cortadeira Acromyrmex heyeri Forel (Hymenoptera, Formicidae). A migração de colônias de formigas cortadeiras é um fenômeno pouco estudado. Nesse estudo, nós relatamos a emigração de uma colônia da formiga cortadeira A. heyeri no Brasil. A colônia emigrou 47,5 m de distância do seu ninho original para um novo local, provavelmente porque sofreu um estresse considerável devido à interações competitivas com uma colônia de Acromyrmex crassispinus.

PALAVRAS-CHAVE. Agressão inter-especifica; Attini; formigas cortadeiras; transferência de ninho.

Species of the tribe Attini are unique among ants in their habit of growing fungus for food, relying heavily on it for their nutrition (Mehdiabadi \& Schultz 2009). Among the attines, ants of genera Acromyrmex and Atta, the so-called leaf-cutting ants, exhibit the most complex fungus-growing systems. Leaf-cutting ants are among the most polymorphic of all social insects and show extensive division of labor among size castes (Hölldobler \& Wilson 2008). Foraging is done by medium- to large-sized workers that cut and collect small leaf fragments, which they transport along trails to the nest, where this material is further processed by smaller workers and incorporated into the fungus garden, which is then consumed by the ants and their brood (Hölldobler \& Wilson 2008).

Leaf-cutting ants are characteristic faunal elements of the Neotropics, and, as such, they must possess adaptations to respond to environmental perturbations that could threaten colony survivorship (Fowler 1981). One such adaptation is the possibility of colony emigration, yet this phenomenon is poorly studied in leaf-cutting ants (Fowler 1981). The present study reports on a case of emigration of a colony of the leaf-cutting ant Acromyrmex heyeri Forel 1899 (Hymenoptera, Formicidae).

The observations were carried out during another study on the foraging ecology of Acromyrmex crassispinus (Forel, 1909 ), when the emigration of a colony of $A$. heyeri was ob- served in a disturbed area dominated by grasses and small shrubs in the campus of the Universidade Federal do Paraná, in Curitiba, state of Paraná, Brazil $\left(25^{\circ} 26^{\prime} 56.54^{\prime \prime S}\right.$, $\left.49^{\circ} 13^{\prime} 56.22^{\prime \prime} \mathrm{W}\right)$. The observations were carried out during the day and included recording the duration and the distance of the nest relocation.

The colony of $A$. heyeri was observed emigrating to a new micro-habitat for several days, between 4 and 14 February 2011. The linear distance from the original to the new nest was $28.33 \mathrm{~m}$, whereas the actual trail distance was 47.40 m. Eggs, larvae, pupae and minor workers were observed being transported to the new nest, although the flow of ants along the trail was low (approximately 3 ants/hour). There was no observation of transportation of pieces of the fungus garden during observations.

In the present study, the observations were carried out during the day and were characterized by a low flow of ant workers transporting the brood to the new nest. It is possible that a more intense flow of ants transporting the brood and the transfer of pieces of the fungus garden to the new nest took place at night to avoid desiccation. To the best of our knowledge, this study was the third report of colony migration in Acromyrmex (Fowler 1977, 1981), which include the duration and the distance of the nest displacement, and the first record in $A$. heyeri, although previous records were avail- 
able for Atta (see Autuori 1941; Fowler 1981; Fowler 1994; Porter \& Bowers 1980; Rockwood 1973).

Brood exchange between two nests of Atta vollenweideri (Forel, 1939) was reported from the lower Paraguayan Chaco. Atta vollenweideri brood was transported in only one direction, with no visible aggression between workers of either nest. However, it was not certain whether this behavior was an indication of nest robbing, polygynous or polydomous social organization, or nest emigration (Fowler 1994). Nest relocation of colonies were reported in A. crassispinus in Rio Negrinho and Três Barras, Santa Catarina, Brazil (Nickele et al. 2009) and Acromyrmex octospinosus (Reich, 1793) in central Panamá (Fernández-Marin et al. 2004), however the authors did not record the duration and the distance of the nest relocation.

Emigration of Atta colombica (Guérin, 1845) lasted for eight days and was nocturnal in Barro Colorado Island, Panama, beginning around dusk and ceasing around sunrise (Porter \& Bowers 1980). Atta sexdens (L.) emigrates underground in São Paulo, Brazil, at a depth of $1.65 \mathrm{~m}$ (Autuori 1941). Emigration of a colony of $A$. crassispinus lasted 24 hours on the grounds of the Universidad Nacional de Asuncion, near San Lorenzo, Paraguay (Fowler 1977). Colonies of Acromyrmex rugosus (F. Smith, 1858) in Paraguay emigrated to new nest sites, but the entire migration took place during a single night (Fowler 1981).

The trail distance used by $A$. heyeri was $47.4 \mathrm{~m}$. Colonies of $A$. rugosus in Paraguay emigrated to new nest sites more than $60 \mathrm{~m}$ from the original nest (Fowler 1981). A colony of A. crassispinus emigrated to a new location $60 \mathrm{~m}$ away (Fowler 1977). The most distant nest relocation registered to $A$. sexdens was $320 \mathrm{~m}$ (Fowler 1981). Emigration of $A$. colombica from its old mound site to a new one was 200 (Rockwood 1973) to 270 m (Porter \& Bowers 1980).

There are four explanations why leaf-cutting ants relocate their nests. First, nest relocation may occur due to repeated applications of insecticides. Three colonies of $A$. sexdens were observed emigrating followed baiting with a toxicant (Fowler 1981). Flooding can be another factor that initiates a colony emigration. A colony of $A$. colombica was completely submerged for about 5 days. When the water level dropped, the colony moved to a higher region (Rockwood 1973). Emigration may occur due to poor foraging conditions. For instance, a colony of $A$. colombica emigrated because its foraging dropped to extremely low levels for more than two weeks during the dry season. Also, their foraging area was ploughed and planted with sorghum (Rockwood 1973). Finally, leaf cutting ants are known to emigrate following intra and interspecific aggression. For example, aggressions between colonies of the leaf-cutting ants $A$. crassispinus and $A$. sexdens were observed, such that $A$. sexdens dominated the $A$. crassispinus nest, but did not overcome it (Fowler 1977). The $A$. crassispinus nest was subsequently raided by Labidus praedator (Fr. Smith, 1858), which took larvae and pupae without killing the colony. The result was the nest displacement of the attacked $A$. crassispinus colony (Fowler 1977).

In the present study, the $A$. heyeri colony had undergone considerable stress before it moved. Its foraging area was reduced by competitive pressure with an $A$. crassispinus colony (MAN, personal observation). The foraging trail of $A$. crassispinus reached the foraging trail of $A$. heyeri and there was interspecific aggression between workers along the trail (MAN, personal observation). By moving, $A$. heyeri colony freed itself of competitive pressure from $A$. crassispinus colony and established itself in a new area where it could expand its foraging range.

\section{ACKNOWLEDGMENTS}

We thank the Coordenação de Aperfeiçoamento de Pessoal de Nível Superior (CAPES) for granting fellowship to M.A.N. and Battistella Florestal for financial support.

We also thank Martin Bollazzi for assistance in the species identification.

\section{REFERENCES}

Autuori, M. 1941. Contribuição para o conhecimento da saúva (Atta spp. Hymenoptera: Formicidae) I - Evolução do sauveiro (Atta sexdens rubropilosa Forel, 1908). Arquivos do Instituto Biológico 12: 197-228.

Fernández-Marín, H.; J. K. Zimmerman \& W. T. Wcislo. 2004. Ecological traits and evolutionary sequence of nest establishment in fungusgrowing ants (Hymenoptera, Formicidae, Attini). Biological Journal of the Linnean Society 81: 39-48.

Fowler, H. G. 1977. Field response of Acromyrmex crassispinus (Forel) to aggression by Atta sexdens (Linn.) and predation by Labidus predator (Fr. Smith) (Hymenoptera: Formicidae). Aggressive Behavior 3: 385-391.

Fowler, H. G. 1981. On the emigration of leaf-cutting ants colonies. Biotropica 13: 316.

Fowler, H. G. 1994. Brood exchange between nest mounds of Atta vollenweideri (Forel) (Hymenoptera, Formicidae). Revista Brasileira de Entomologia 38: 97-99.

Hölldobler, B. \& E. O. Wilson. 2008. The Superorganism: The Beauty, elegance, and strangeness of insect societies. New York, W.W. Norton \& Co., 544 p.

Mehdiabadi, N. J. \& T. R. Schultz. 2009. Natural history and phylogeny of the fungus-farming ants (Hymenoptera: Formicidae: Myrmicinae: Attini). Myrmecological News 13: 37-55

Nickele, M. A.; W. Reis Filho; E. B. de Oliveira \& E. T. Iede. 2009. Densidade e tamanho de formigueiros de Acromyrmex crassispinus em plantios de Pinus taeda. Pesquisa Agropecuária Brasileira 44: 347-353.

Porter, S. D. \& M. A. Bowers. 1980. Emigration of an Atta colony. Biotropica 12: 232-233.

Rockwood, L. L. 1973. Distribution, density, and dispersion of two species of Atta (Hymenoptera: Formicidae) in Guanacaste Province, Costa Rica. Journal of Animal Ecology 42: 803-817. 